\title{
Tramas e dramas de gênero e de cor: a violência doméstica e familiar contra mulheres negras
}

\author{
Bruna Cristina Jaquetto Pereira \\ Orientador: Prof. Dr. Tânia Mara Campos de Almeida \\ Curso: Mestrado em Sociologia \\ Data da Defesa: 10.04.2013
}

\begin{abstract}
A presente dissertação tem por tema a violência doméstica e familiar contra mulheres negras. Promovo uma interlocução entre formulações teóricas e pesquisas empíricas consagradas sobre a violência doméstica e familiar contra as mulheres, inscritas no campo das ciências sociais, e o material recolhido em trabalho de campo, bem como busco reconstruir e perscrutar os cenários construídos pelas narrativas das informantes, com vistas a identificar práticas, dinâmicas, representações, sentidos e significados que digam respeito simultaneamente à cor/raça e ao gênero, que participem ou tenham implicações para a situação de violência doméstica. O objetivo foi investigar se e de que modo a cor/raça, em seu entrecruzamento com o gênero, participa da situação de violência doméstica e familiar contra as mulheres negras. Foi possível constatar que as interações pessoais no âmbito doméstico e familiar, bem como a violência travada em tal domínio, estão entremeadas por expectativas, significados e constituições identitárias que derivam da articulação entre as dimensões de gênero e de raça. De forma geral, foram encontradas convergências entre representações sociais das mulheres pretas e pardas e a forma como as mulheres negras inserem-se na situação de violência, bem como sentidos e modelos de feminilidade que destoam daquele que é tido como referencial e que é abordado hegemonicamente nos estudos de gênero. Adicionalmente, constatou-se a relevância da cor dos/das filhos/filhas como fator desencadeado da violência e também a ausência de referências às violências pautadas na cor/raça como violência doméstica e familiar - ainda quando decorrida nesse âmbito.
\end{abstract}

Palavras-chave: Violência Doméstica e Familiar, Mulheres Negras, Gênero, Cor/ Raça. 